\title{
Leptin Rapidly Suppresses Insulin Release from Insulinoma Cells, Rat and Human Islets and, In Vivo, in Mice
}

\author{
Rohit N. Kulkarni, Zhi-Li Wang, Ren-Ming Wang, James D. Hurley, David M. Smith, Mohammad A. Ghatei, Dominic J. Withers, \\ James V. Gardiner, Cliff J. Bailey, ${ }^{\star}$ and Stephen R. Bloom \\ Division of Endocrinology, Department of Metabolic Medicine, Royal Postgraduate Medical School, Hammersmith Hospital, London \\ W12 0NN, United Kingdom; and *Department of Pharmaceutical and Biological Sciences, Aston University, Birmingham B4 7 ET, \\ United Kingdom
}

\begin{abstract}
Obesity is associated with diabetes, and leptin is known to be elevated in obesity. To investigate whether leptin has a direct effect on insulin secretion, isolated rat and human islets and cultured insulinoma cells were studied. In all cases, mouse leptin inhibited insulin secretion at concentrations within the plasma range reported in humans. Insulin mRNA expression was also suppressed in the cultured cells and rat islets. The long form of the leptin receptor (OB-Rb) mRNA was present in the islets and insulinoma cell lines. To determine the significance of these findings in vivo, normal fed mice were injected with two doses of leptin. A significant decrease in plasma insulin and associated rise in glucose concentration were observed. Fasted normal and leptin receptor-deficient $d b / d b$ mice showed no response to leptin. A dose of leptin, which mimicked that found in normal mice, was administered to leptin-deficient, hyperinsulinemic $o b / o b$ mice. This caused a marked lowering of plasma insulin concentration and a doubling of plasma glucose. Thus, leptin has a powerful acute inhibitory effect on insulin secretion. These results suggest that the action of leptin may be one mechanism by which excess adipose tissue could acutely impair carbohydrate metabolism. (J. Clin. Invest. 1997. 100:2729-2736.) Key words: leptin • insulin • islet $\bullet \beta$ cells $\cdot$ suppression
\end{abstract}

\section{Introduction}

The $o b$ gene product, leptin, is a $16-\mathrm{kD}$ protein secreted primarily by adipocytes (1). Circulating leptin levels correlate well with the percent body fat, suggesting that the production of leptin is regulated by adipocyte mass $(2,3)$. Several studies have shown that one of the sites of action of leptin in regulating body weight and energy balance is the hypothalamus (4-6). However, other reports suggest a peripheral role for leptin in hemopoiesis and modulation of insulin activities in the liver (7,

Address correspondence to Prof. S.R. Bloom, Division of Endocrinology, Department of Metabolic Medicine, Royal Postgraduate Medical School, Hammersmith Hospital, Du Cane Rd., London W12 0NN, UK. Phone: 44-181-383-3242; FAX: 44-181-383-3142; E-mail: sbloom@rpms.ac.uk R.N. Kulkarni's present address is Joslin Diabetes Center and Department of Medicine, Harvard Medical School, Boston, MA 02215.

Received for publication 17 March 1997 and accepted in revised form 24 September 1997.

J. Clin. Invest.

(C) The American Society for Clinical Investigation, Inc. 0021-9738/97/12/2729/08 \$2.00

Volume 100, Number 11, December 1997, 2729-2736

http://www.jci.org
8). Food intake causes an increase in leptin mRNA levels, an effect that is mimicked by insulin administration in fasted rats, suggesting a relationship between food intake, insulin levels, and leptin synthesis in rats (9). Recent studies have shown an increase in leptin levels in normal and non-insulin-dependent diabetes mellitus subjects after an insulin infusion (10). In addition, insulin resistance has been reported to be associated with high plasma leptin levels independent of body fat (11). These observations suggest that important interactions exist between leptin and insulin, with insulin regulating the expression of leptin. A recent study has reported the presence of leptin receptors on $\beta$ cells (12) and the authors proposed that leptin may inhibit insulin secretion forming an adipoinsular feedback loop. This speculation has been supported by the demonstration of a direct inhibitory effect of leptin on insulin release in islets isolated from normal and $o b / o b$ mice (13). Our pilot data from freely moving mice and isolated human islets showed similar effects to the islet study. However, a study in the perfused rat pancreas showed no effect of leptin on insulin and glucagon release (14). Therefore, in this study, we investigated the effect of recombinant mouse leptin both in vitro in insulinoma cells and isolated rat and human islets and in vivo in normal, $o b / o b$, and $d b / d b$ mice to verify whether there was an acute effect of leptin on insulin secretion.

\section{Methods}

Chemical sources. Recombinant mouse leptin ( $>90 \%$ pure as determined by SDS-PAGE) was obtained from Dr. M. Chiesi and Dr. N. Levens (Ciba-Geigy Ltd., Basel, Switzerland) and demonstrated to be endotoxin free (i.e., below the detection limit by the Limulus amebocyte lysate method). The batches of leptin used in this study have been shown previously to potently inhibit food intake in normal mice (15). Tolbutamide, arginine, and all other chemicals, unless specified, were of analar grade and were obtained from Sigma Chemical Co. (Poole, Dorset, UK).

Islet experiments. Male Wistar rats $(\sim 250 \mathrm{~g}$ body $\mathrm{wt})$ were obtained from Bantin and Kingman (Hull, UK). Islets were isolated as described earlier (16). Briefly, the common bile duct was cannulated in the anterograde direction and the pancreas distended with collagenase (type $\mathrm{P}, 4 \mathrm{mg}$ in $5 \mathrm{ml}$; Boehringer Mannheim, Mannheim, Germany), dissected free, and incubated at $37^{\circ} \mathrm{C}$ for $12 \mathrm{~min}$. Washed, hand-picked islets (100-200 per chamber) were perifused $(0.4 \mathrm{ml} /$ min) with a $50: 50$ (vol/vol) mixture of $\mathrm{KRB}$ buffer $(\mathrm{pH} 7.4)$ and CMRL 1066 media (GIBCO BRL, Paisley, UK) plus $2.8 \mathrm{mmol}$. liter ${ }^{-1}$ glucose at $37^{\circ} \mathrm{C}$, gassing with $95 \%$ oxygen $/ 5 \%$ carbon dioxide $(16,17)$. Leptin was added to the perifusion buffer for $40 \mathrm{~min}(81-120$ $\mathrm{min}$ ) in the presence of $8 \mathrm{mmol} \cdot$ liter $^{-1}$ glucose. Islet cell viability was assessed by stimulation with high glucose $\left(16 \mathrm{mmol}^{-}\right.$liter $\left.^{-1}\right)$ from 201 to $220 \mathrm{~min}$. The effects of leptin were compared with paired control chambers run synchronously from a single harvest pool.

For static incubation experiments on human islets, pancreata were removed from brain-dead heart-beating donors after informed consent was obtained from their next of kin, and islets were prepared 
as described previously (Leicester Royal Infirmary, Leicester, UK) (18). Islets were cultured in RPMI 1640 medium $\left(5.5 \mathrm{mmol} \cdot\right.$ liter $^{-1}$ glucose, $10 \%$ FCS, $100 \mathrm{U} / \mathrm{ml}$ penicillin, and $100 \mu \mathrm{g} / \mathrm{ml}$ streptomycin). Groups of islets $\left(100\right.$ islets $\left.\cdot \mathrm{ml}^{-1}\right)$ were incubated with leptin in 6-well plates for $16 \mathrm{~h}$

Medium from islet experiments was removed, centrifuged at $1,000 \mathrm{~g}$ for $5 \mathrm{~min}$, and assayed for insulin by RIA. Antibody (Glu5) was raised in a guinea pig against porcine insulin conjugated to BSA by glutaraldehyde and used at a final dilution of 1:800,000 (19). This antibody cross-reacts fully with human and rat insulin. Radiolabeled ${ }^{125} \mathrm{I}$-porcine insulin was prepared by the iodogen method and purified by HPLC. The assay was carried out in $0.8 \mathrm{ml}$ of $0.06 \mathrm{~mol} \cdot$ liter $^{-1}$ phosphate/EDTA buffer, $\mathrm{pH} 7.4$, containing $0.3 \%$ (wt/vol) BSA and can detect changes of 2.5 fmol between adjacent tubes within $95 \%$ confidence limits.

Cell culture. $\beta$ TC6 cells were obtained from Dr. S. Efrat (Albert Einstein College of Medicine, New York) and cultured in DME medium with $15 \%$ ( vol/ $/ \mathrm{vol}$ ) horse serum, $2.5 \%$ ( vol/ $/ \mathrm{vol}) \mathrm{FCS}$, and antibiotics (20). RIN 5AH (a gift from Dr. A.E. Karlsson, Hagedorn Research Laboratory, Gentofte, Denmark; passages 14-24) and RIN m5F cells (a gift from Dr. S.J. Ashcroft, Physiology Department, Oxford University, UK; passages 84-100) were cultured in RPMI 1640 medium with $10 \%$ FCS (21). Cells were subcultured with EDTA and trypsin $(0.05 \%)$ in calcium-free and magnesium-free Hank's solution. For experiments, cells were plated at a density of $20-50 \times 10^{5}$ cells in 100 -mm culture plates in $10 \mathrm{ml}$ of medium ( $\beta$ TC6) or $1-2 \times 10^{5}$ cells/ well in 24-well plates in $1 \mathrm{ml}$ of medium (RIN 5AH, RIN m5F). Cells were incubated for 48-72 $\mathrm{h}$ to allow attachment, before changing the medium. After a further $48-72 \mathrm{~h}$, when $70 \%$ confluent, $\beta$ TC6 cells were rinsed with serum-free DME medium and incubated with glucose-free KRB buffer for $1 \mathrm{~h}$. This was followed by incubation of the cells for up to $2 \mathrm{~h}$ with KRB buffer containing glucose $(5.5 \mathrm{mmol}$. liter ${ }^{-1}$ ) and leptin. The time course experiment using $\beta$ TC6 cells involved incubation with $1 \mathrm{nmol} \cdot$ liter $^{-1}$ leptin. RIN cells were treated in a similar manner, except preincubation was for $2 \mathrm{~h}$ in serum-free glucose-free RPMI 1640 followed by $2 \mathrm{~h}$ of incubation in serum-free RPMI 1640 supplemented with glucose $\left(1.2 \mathrm{mmol}^{-}\right.$liter $^{-1}$, RIN $5 \mathrm{AH})$ or glyceraldehyde $\left(15 \mathrm{mmol} \cdot\right.$ liter $^{-1}$, RIN m5F). Medium was collected for insulin measurement by RIA (19). Cell viability and cell counts were measured using trypan blue exclusion.

Northern blot analysis. Total RNA was extracted using guanidinium thiocyanate-phenol-chloroform (22). Northern blot analysis was performed with a cDNA probe corresponding to the coding region of rat insulin I as described previously (23). Briefly, $50 \mu \mathrm{g}$ RNA was separated on a denaturing Mops/formaldehyde gel (1\% [wt/vol] agarose) and transferred to a Hybond-N membrane (Amersham International plc, Buckinghamshire, UK). The RNA was fixed by baking at $80^{\circ} \mathrm{C}$ for $2 \mathrm{~h}$. The cDNA probe was prepared by random primer extension using $\left[\alpha{ }^{32} \mathrm{P}\right] \mathrm{dCTP}$ (Amersham) and Klenow fragment (Pharmacia Biotechnology Ltd., St. Albans, Hertfordshire, UK). Hybridization was carried out overnight at $42^{\circ} \mathrm{C}$ in $50 \%(\mathrm{vol} / \mathrm{vol})$ formamide; $5 \times$ SSC $\left(1 \times\right.$ SSC contains $0.15 \mathrm{~mol} \cdot$ liter $^{-1}$ sodium chloride; $15 \mathrm{mmol} \cdot$ liter ${ }^{-1}$ sodium citrate); $5 \times$ Denhardt's solution; $100 \mu \mathrm{g} / \mathrm{ml}$ of denatured sonicated herring sperm DNA; and $10 \%$ (wt/vol) dextran sulfate with $2 \mathrm{ng} / \mathrm{ml}$ of radioactively labeled probe. The filter was washed twice at room temperature for $10 \mathrm{~min}$ in $2 \times \mathrm{SSC}, 0.2 \%(\mathrm{wt} /$ vol) SDS, and once at $60^{\circ} \mathrm{C}$ for $20 \mathrm{~min}$ in $0.1 \times \mathrm{SSC} / 0.1 \%$ SDS. Signals were quantified on a PhosphorImager (Molecular Dynamics, Sunnyvale, CA) using Imagequant software (Molecular Dynamics). The data were normalized by reprobing the blot with terminal transferase-labeled oligo(dT) $)_{12-17}$ and requantification (24). Results are expressed in arbitrary units calculated as a ratio of the insulin mRNA signal to the oligo(dT) signal. Autoradiography of the filter was carried out at $-70^{\circ} \mathrm{C}$ using Kodak X-OMAT ${ }^{\mathrm{TM}}$ and an intensifying screen for $3 \mathrm{~d}$.

PCR and Southern blot analysis. $50 \mu \mathrm{g}$ of RNA was reverse transcribed using 9 U AMV reverse transcriptase (Promega, Southampton, UK) and $200 \mathrm{ng}$ oligo(dT) $)_{12-17}$ in $1 \times$ reverse transcription buffer $\left(50 \mathrm{mmol} \cdot\right.$ liter $^{-1}$ Tris- $\mathrm{HCl}, \mathrm{pH} 8.3,5 \mathrm{mmol} \cdot$ liter $^{-1} \mathrm{KCl}, 1 \mathrm{mmol} \cdot$ liter ${ }^{-1} \mathrm{MgCl}_{2}, 1 \mathrm{mmol} \cdot$ liter $^{-1}$ DTT, $0.5 \mathrm{mmol} \cdot$ liter $^{-1}$ spermidine) and $200 \mu \mathrm{mol} \cdot$ liter $^{-1}$ dNTP. Amplification by PCR was performed using primers derived from the aligned rat and mouse leptin receptor sequences that correspond to nucleotides 3199-3219 (sense) and 3506-3525 (antisense) of the rat leptin receptor sequence (25). PCR was carried out with half the reverse transcription reaction in a solution containing $1 \times T a q$ polymerase buffer $\left(20 \mathrm{mmol} \cdot\right.$ liter $^{-1}$ Tris$\mathrm{HCl}, \mathrm{pH} 8.4,50 \mathrm{mmol} \cdot$ liter $^{-1} \mathrm{KCl}, 1.5 \mathrm{mmol} \cdot$ liter $\left.^{-1} \mathrm{MgCl}_{2}\right), 200$ $\mu \mathrm{mol} \cdot$ liter $^{-1} \mathrm{dNTP}, 200 \mathrm{ng}$ of each primer, and $1 \mathrm{U}$ Taq polymerase using the following program: $95^{\circ} \mathrm{C}$ for $1 \mathrm{~min}, 55^{\circ} \mathrm{C}$ for $45 \mathrm{~s}$, and $72^{\circ} \mathrm{C}$ for $50 \mathrm{~s}$ for 30 cycles followed by a final step of $70^{\circ} \mathrm{C}$ for $10 \mathrm{~min}$. The PCRs were analyzed by Southern blotting using an oligonucleotide probe (nucleotides 3304-3326) $33^{\prime}$ end-labeled with $\left[\alpha-{ }^{32} \mathrm{P}\right] \mathrm{dATP}$ and terminal transferase (Promega) as described previously (26).

Second messenger studies. $\beta$ TC6 cells cultured in $80-\mathrm{cm}^{2}$ flasks were washed in KRB buffer and preincubated in glucose-free and serum-free KRB buffer for $2 \mathrm{~h}$. For intracellular $\mathrm{Ca}^{2+}$ measurements $\left(\left[\mathrm{Ca}^{2+}\right]_{\mathrm{I}}\right),{ }^{1}$ cells were washed in a solution of HBSS (27) and incubated for a further $45 \mathrm{~min}$ at $37^{\circ} \mathrm{C}$ in HBSS containing $2 \mu \mathrm{mol} \cdot$ liter $^{-1}$ Fura-2/AM (Novabiochem, Nottingham, UK). Excess Fura-2/AM was removed by washing with HBSS. Intracellular calcium measurements were carried out using $2 \mathrm{ml}$ of cell suspension at $37^{\circ} \mathrm{C}$ within $2 \mathrm{~h}$ of loading as described earlier $(27,28)$. Briefly, the fluorescence was monitored in a luminescence spectrometer (LS-5; Perkin-Elmer, Norwalk, CT) with an excitation wavelength of $336 \mathrm{~nm}$ and an emission wavelength of $510 \mathrm{~nm}$ using leptin $\left(1 \mathrm{nmol} \cdot \operatorname{liter}^{-1}\right)$ and tolbutamide $\left(100 \mu \mathrm{mol} \cdot \operatorname{liter}^{-1}\right)$ as test substances. $\left[\mathrm{Ca}^{2+}\right]_{\mathrm{I}}$ was calculated using the formula: $\left[\mathrm{Ca}^{2+}\right]_{\mathrm{I}}$ in $\mathrm{nM}=200\left(F-F_{\min }\right) /\left(F_{\max }-F\right)$; where $\mathrm{F}$ is the fluorescence at the unknown $\left[\mathrm{Ca}^{2+}\right]_{\mathrm{I}}, \mathrm{F}_{\max }$ is the fluorescence after the trapped fluorescence is released by the addition of $0.02 \%$ Triton $\mathrm{X}-100$, and $\mathrm{F}_{\min }$ is the fluorescence remaining after the $\mathrm{Ca}^{2+}$ in the solution is chelated with $10 \mathrm{mM}$ EGTA. The change in $\left[\mathrm{Ca}^{2+}\right]_{\mathrm{I}}$ is presented as the increase in $\left[\mathrm{Ca}^{2+}\right]_{\mathrm{I}}$ expressed in $\mathrm{nmol} \cdot \mathrm{liter}^{-1}$. Calibration was carried out by solutions from Molecular Probes (Eugene, OR).

In vivo studies. Normal male (C57B6/CBA) mice ( $\sim 25 \mathrm{~g}$ body wt $)$ were housed in a 12-h dark/light cycle and allowed chow and water ad libitum. $1 \mathrm{wk}$ before the experiment, animals were fasted overnight and trained to consume food for $1 \mathrm{~h}$ (09:00 to 10:00) as described previously (29). On the experimental day, $30 \mathrm{~min}$ after feeding, mice were injected intraperitoneally with $200 \mu \mathrm{l} 0.9 \%$ saline (vehicle control), or leptin at $0.02 \mathrm{or} 1.0 \mu \mathrm{g} \cdot \mathrm{g}^{-1}$ body wt. A further group of normal mice was injected with either saline or leptin $\left(1.0 \mu \mathrm{g} \cdot \mathrm{g}^{-1}\right.$ body wt) after an overnight fast.

Male $o b / o b$ ( 80 g body wt; Aston University, Birmingham, UK), young male $d b / d b$ (35 g body wt; Harlan Bicester, Oxford, UK), or heterozygous $d b /+$ mice ( $25 \mathrm{~g}$ body wt) were housed and fed as described above. Mice were fed overnight and food was removed $30 \mathrm{~min}$ before intraperitoneal injection of saline or leptin at $0.02 \mu \mathrm{g} \cdot \mathrm{g}^{-1}$ body wt $(\mathrm{ob} / \mathrm{ob}$ and $d b / d b)$ or $0.2 \mu \mathrm{g} \cdot \mathrm{g}^{-1}$ body wt $(\mathrm{db} / \mathrm{db})$ in $200 \mu \mathrm{l}$ of saline.

All experiments were randomized and blood was collected by terminal cardiac puncture of different animals for each time point $(n=$ 5-10 per time point per group) with the injection at time 0 . Separate groups of controls injected intraperitoneally with $200 \mu \mathrm{l}$ of $0.9 \%$ saline were included for each dose of leptin. Blood was immediately centrifuged and the plasma was separated and stored at $-20^{\circ} \mathrm{C}$ for measurement of glucose and insulin (RIA) (19). Glucose was measured by the glucose oxidase method (YSI 2300 glucose analyzer; YSI Bioanalytical Products, Yellow Springs, OH). Mouse leptin concentrations were measured in test solutions and plasma by an established RIA kit (Linco Research Inc., St. Charles, MO).

All animal procedures were performed according to British Home Office regulations.

1. Abbreviations used in this paper: AUC, area under curve; $\left[\mathrm{Ca}^{2+}\right]_{\mathrm{I}}$, intracellular calcium concentration. 
Statistical analysis. Results are expressed as mean \pm SE. The comparisons between groups were made using ANOVA with post-hoc Tukey test.

\section{Results}

Islet experiments. Using a perifusion system, a $53 \%$ decrease in glucose-stimulated $\left(8 \mathrm{mmol} \cdot\right.$ liter $\left.^{-1}\right)$ insulin release was observed when mouse leptin $\left(100 \mathrm{pmol} \cdot\right.$ liter $\left.^{-1}\right)$ was added to rat islets (leptin 11.2 \pm 1.4 vs. control $21.0 \pm 0.9 \mathrm{fmol}^{-}$islet $^{-1}$. $\min ^{-1}, n=6, P<0.001$, Fig. $1 a$ ). Isolated human islets were studied in static incubation. Leptin inhibited insulin secretion in $5.5 \mathrm{mmol} \cdot$ liter $^{-1}$ glucose by $\sim 77 \%$ at $1 \mathrm{nmol} \cdot$ liter $^{-1}$ (leptin $31.8 \pm 4.6$ vs. control $139.6 \pm 13.5 \mathrm{fmol} \cdot \mathrm{ml}^{-1} \cdot \mathrm{h}^{-1}, P<0.001$, $n=6$, Fig. $1 b$ ). Thus, an inhibitory effect of mouse leptin on insulin secretion was observed in the islets.
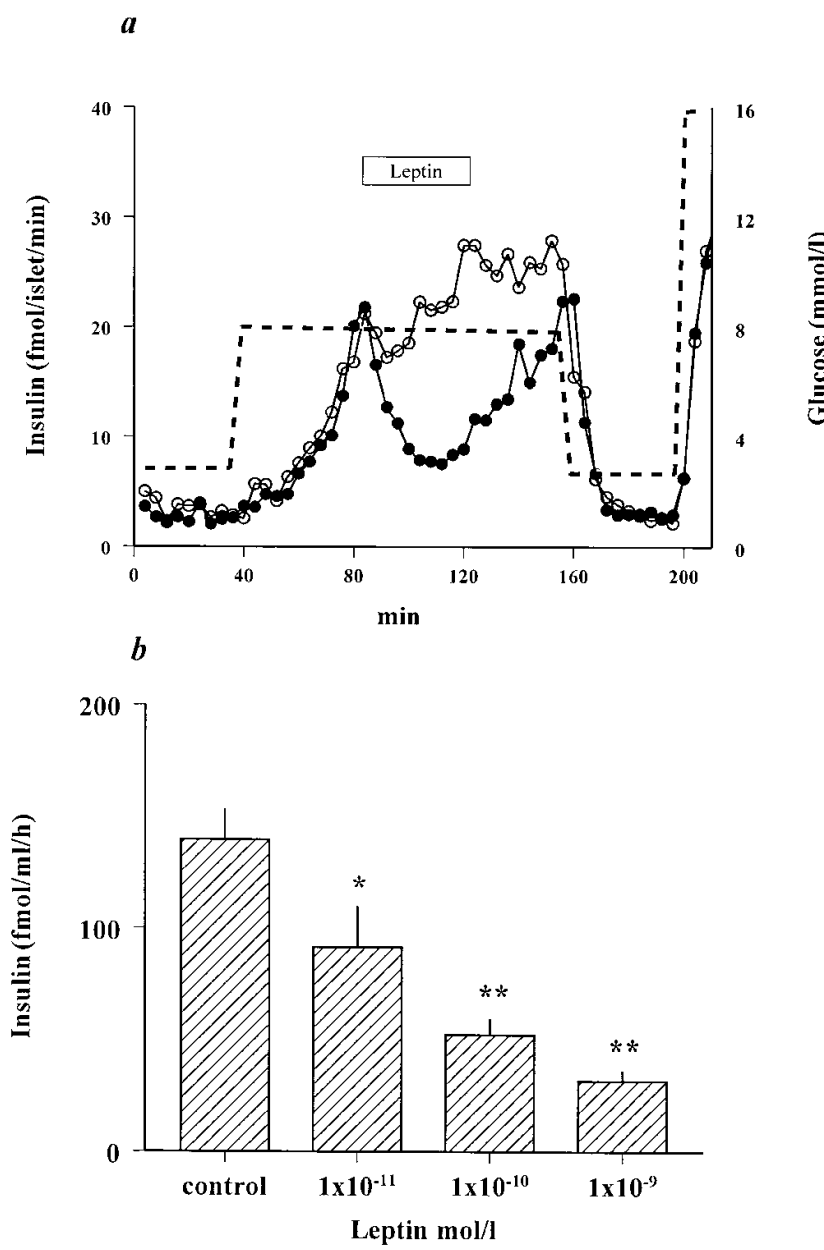

Figure 1. (a) Insulin release from perifused rat islets. In the perifused islets, leptin $\left(100 \mathrm{pmol} \cdot \mathrm{liter}^{-1}\right)$ was added from 81 to $120 \mathrm{~min}$. Glucose concentration was $2.8 \mathrm{mmol} \cdot$ liter $^{-1}$ from 0 to 40 and 161 to 200 min, $8 \mathrm{mmol} \cdot$ liter $^{-1}$ from 41 to $160 \mathrm{~min}$, and $16 \mathrm{mmol} \cdot$ liter $^{-1}$ from 201 to $220 \mathrm{~min}$. Data are mean values \pm SE, $n=6$. ${ }^{*} P<0.01$, leptin treated (filled circles) vs. control (open circles). The comparisons between groups were made using ANOVA with post-hoc Tukey test. (b) Insulin release from static incubation of human islets. Glucose concentration was $5.5 \mathrm{mmol} \cdot \operatorname{liter}^{-1}$. Data are means \pm SE, $n=6$. The comparisons between groups were made using ANOVA with posthoc Tukey test. $* P<0.02, * * P<0.001$ vs. control.
Cell culture experiments. The effect of leptin on mouse and rat insulinoma cells was investigated. In mouse $\beta$ TC6 cells, leptin suppressed insulin release stimulated with $5.5 \mathrm{mmol}$. liter $^{-1}$ glucose by $56 \%$ at $10 \mathrm{nmol} \cdot \operatorname{liter}^{-1}(P<0.001$ vs. control, $n=9$, Fig. $2 a$ ). The inhibition in $\beta$ TC6 cells was seen at $10 \mathrm{~min}$ and achieved a maximum by $60 \mathrm{~min}(P<0.01, n=6$, Fig. 2 b). Similar responses were observed in the rat cell lines, with an inhibitory effect at $1 \mathrm{nmol} \cdot \operatorname{liter}^{-1}$ in RIN 5AH cells (leptin $0.54 \pm 0.06$ vs. control $0.81 \pm 0.06 \mathrm{pmol} / 10^{6}$ cells $\cdot \mathrm{h}^{-1}$, $P<0.01, n=12$ ) and at $1 \mathrm{nmol} \cdot \operatorname{liter}^{-1}$ in RIN m5F cells (leptin $4.2 \pm 0.2$ vs. control $5.7 \pm 0.4 \mathrm{pmol} / 10^{6}$ cells $\cdot \mathrm{h}^{-1}, P<0.01$, $n=8)$. In the $\beta$ TC6 cells, leptin $\left(1 \mathrm{nmol} \cdot \operatorname{liter}^{-1}\right)$ did not alter the stimulatory effect of tolbutamide $\left(100 \mu \mathrm{mol} \cdot\right.$ liter $\left.^{-1}\right)$ or arginine $\left(10 \mathrm{mmol} \cdot\right.$ liter $\left.^{-1}\right)$ on insulin release (Table I).

Northern blot analysis. Leptin suppressed insulin mRNA expression in both isolated rat islets and $\beta$ TC6 cells (Fig. $3 a$ ). For example, a $38 \pm 7 \%$ (islets) and $28 \pm 6 \%$ ( $\beta$ TC6) decrease in insulin mRNA $(n=4)$ was evident at $1 \mathrm{nmol} \cdot \operatorname{liter}^{-1}$ leptin, compared with untreated controls.

PCR and Southern blot analysis. The presence of leptin receptor mRNA has been described recently in $\beta$ cells $(12,13)$. Using RT-PCR with long isoform specific primers (30), we generated a band from RNA prepared from rat hypothalamus, but not kidney or colon, the latter two tissues only expressing the short form of the receptor (30) (Fig. $3 \mathrm{~b}$ ). We found leptin receptor mRNA to be present in the insulinoma cell lines, rat islets, and mouse pancreas (Fig. $3 \mathrm{~b}$ ). The leptin receptor long isoform is the form thought to activate intracellular signaling (30). Its presence in the islets and cell lines suggests it could mediate the insulin inhibitory action of leptin. No mRNA for leptin itself could be detected using a cDNA probe in poly $(\mathrm{A})^{+}$prepared from RNA from any of the tissues or the cell lines, except adipose tissue as reported earlier (1).

Second messenger studies. In $\beta$ TC6 cell suspensions, leptin at the concentration of $1 \mathrm{nmol} \cdot$ liter $^{-1}$ showed a $20 \%$ decrease in $\left[\mathrm{Ca}^{2+}\right]_{\mathrm{I}}$, although this was not significantly different from control values. Subsequent addition of tolbutamide $(100 \mu \mathrm{mol}$. liter $\left.^{-1}\right)$, known to elevate $\left[\mathrm{Ca}^{2+}\right]_{\mathrm{I}}$, caused a rapid mobilization, which was unaffected by $1 \mathrm{nmol} \cdot$ liter $^{-1}$ leptin (Table II).

In vivo studies: normal mice. The effects of intraperitoneal injection of leptin were investigated in normal fed mice at 0.02 and $1.0 \mu \mathrm{g} \cdot \mathrm{g}^{-1}$ body wt (31). A significant suppression of insulin release was observed in both fed treated groups in the period from 0 to $70 \mathrm{~min}$ after the injection (incremental area under the curve from 0 to $70 \mathrm{~min}$ [AUC 0-70, nmol $\cdot$ liter $^{-1}$. min]: control $-2 \pm 7$ vs. leptin $0.02 \mu \mathrm{g},-25 \pm 8, P<0.05$; control $4 \pm 9$ vs. leptin $1.0 \mu \mathrm{g},-33 \pm 7, P<0.01$, Fig. $4, a$ and $b$ ) and this suppression occurred in the face of an increase in plasma glucose levels in the same period (AUC 0-70, mmol $\cdot$ liter $^{-1}$. min: control $-3.6 \pm 28$ vs. leptin $0.02 \mu \mathrm{g}, 151 \pm 34, P<0.05$; control $-10 \pm 58$ vs. leptin $1.0 \mu \mathrm{g}, 123 \pm 32, P<0.01$, Fig. $4, c$ and $d$ ). The increase in glucose concentration after leptin treatment is thus likely to be a consequence of the fall in the plasma insulin concentration. These effects were apparent as early as $10 \mathrm{~min}$ after injection in both groups of leptin-treated fed mice. The suppressed insulin levels were not significantly different from control values at $70 \mathrm{~min}$ after injection in mice treated with the $0.02 \mu \mathrm{g}$ dose (control $728 \pm 77$ vs. leptin $639 \pm 88 \mathrm{pmol} \cdot$ liter $^{-1}$ ) but continued to be low in mice treated with the $1.0 \mu \mathrm{g}$ dose (control $838 \pm 156 \mathrm{vs}$. leptin $269 \pm 49 \mathrm{pmol}$. liter ${ }^{-1}$ ). Both doses produced plasma leptin concentrations at $25 \mathrm{~min}$ (leptin $0.02 \mu \mathrm{g}, 11 \pm 4 \mathrm{ng} \cdot \mathrm{ml}^{-1}$ and leptin $1.0 \mu \mathrm{g}$, 

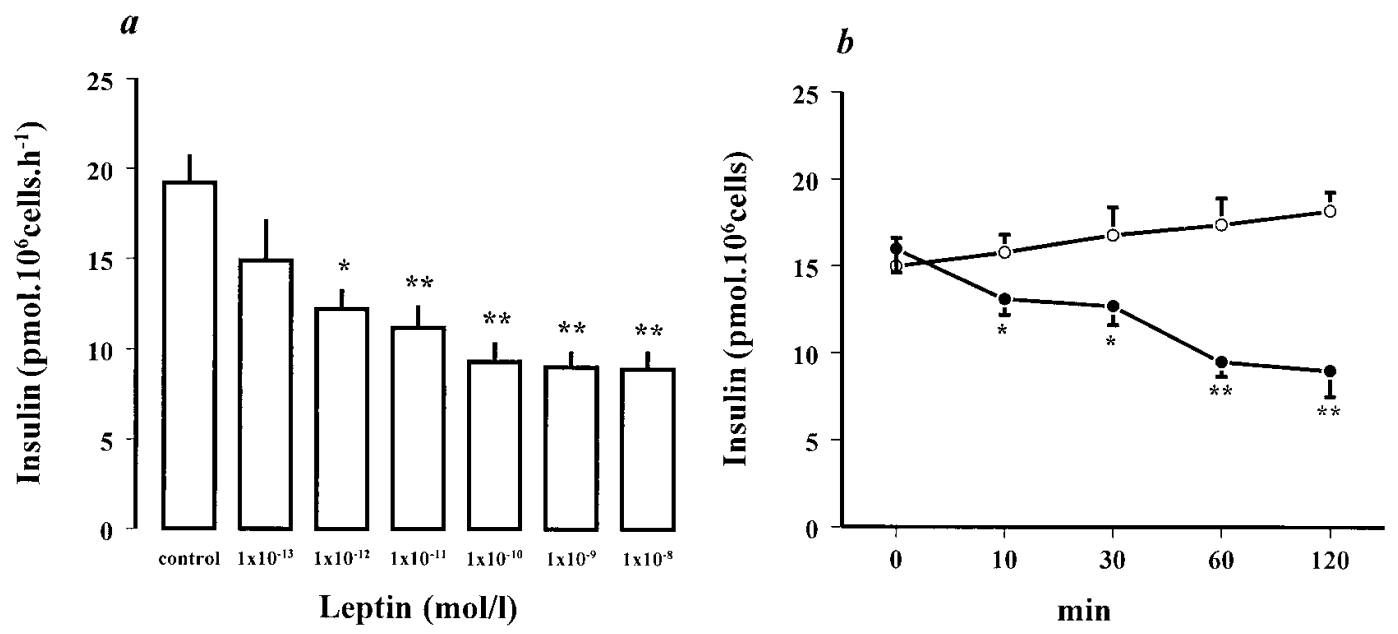

Figure 2. (a) Leptin

dose-response on insulin release from mouse $\beta$ TC6 cells (glucose $5.5 \mathrm{mmol}$. $\left.\operatorname{liter}^{-1}, n=9\right)$. (b) Time course of insulin suppression in response to 1 $\mathrm{nmol} \cdot$ liter $^{-1}$ leptin in $\beta$ TC6 cells $(n=6)$, leptin (filled circles) vs. control (open circles). Data are means \pm SE. The comparisons between groups were made using ANOVA with post-hoc Tukey test. $* P<0.02$, $* * P<0.001$ vs. control.

$\left.580 \pm 172 \mathrm{ng} \cdot \mathrm{ml}^{-1}\right)$ above the levels in the saline-treated controls $\left(4.0 \pm 1.8 \mathrm{ng} \cdot \mathrm{ml}^{-1}\right)$. Normal mice fasted overnight showed no significant change in plasma insulin or glucose 25 min after leptin $\left(1.0 \mu \mathrm{g} \cdot \mathrm{g}^{-1}\right.$ body wt) treatment (Table III).

$o b / o b$ and $d b / d b$ mice. Defective leptin production in $o b /$ $o b$ mice produces a model of gross obesity, severe insulin resistance and, usually, mild hyperglycemia $(1,32)$. To determine if leptin alters insulin release at physiological concentrations, $o b /$ $o b$ mice were injected intraperitoneally with saline or leptin at a dose of $0.02 \mu \mathrm{g} \cdot \mathrm{g}^{-1}$ body wt and killed after $25 \mathrm{~min}$. This achieved plasma leptin concentrations similar to those of agematched normal mice (leptin treated $o b / o b$ mice $[n=8]$ $3.3 \pm 0.9 \mathrm{ng} \cdot \mathrm{ml}^{-1}$ vs. normal mice $[n=9] 3.4 \pm 0.2 \mathrm{ng} \cdot \mathrm{ml}^{-1}$ ). Plasma leptin immunoreactivity in the saline-injected control $o b / o b$ mice was low $\left(0.4 \pm 0.1 \mathrm{ng} \cdot \mathrm{ml}^{-1}, n=5, P<0.001\right.$ vs. normal mice $\left.3.4 \pm 0.2 \mathrm{ng} \cdot \mathrm{ml}^{-1}, n=9\right)$ as previously reported (33). The plasma glucose concentration was considerably higher in the leptin-treated mice (leptin $[n=8] 26.0 \pm 4.1$ vs. saline control $\left.[n=5] 12.5 \pm 0.5 \mathrm{mmol} \cdot \operatorname{liter}^{-1}, P<0.05\right)$. In the leptin-treated $o b / o b$ mice, in spite of a marked rise in the glucose concentration, the insulin concentration was reduced (Table III). The increase in glucose concentration after leptin treatment in the $o b / o b$ mice is thus likely to be a consequence of the fall in the plasma insulin concentration. As a control, diabetes $d b / d b$ mice, known to have a nonfunctional leptin receptor (30), were injected with leptin at 0.02 or a 10 -fold higher dose of $0.2 \mu \mathrm{g} \cdot \mathrm{g}^{-1}$ body wt, as described for the $o b / o b$ mice. The homozygous $d b / d b$ mice injected at $0.2 \mu \mathrm{g} \cdot \mathrm{g}^{-1}$ body wt showed no changes in insulin or glucose (Table III). The lean $(\mathrm{db} /+$ and $+/+)$ littermates injected with leptin at $0.2 \mu \mathrm{g} \cdot \mathrm{g}^{-1}$ body wt showed an inhibition of insulin and elevation of glucose similar in magnitude to that found in normal mice (Table III).

\section{Discussion}

This study demonstrates that leptin suppresses insulin release from the endocrine pancreas. We have used isolated human islets in a static culture model and have shown that leptin reduces insulin secretion in the presence of glucose $(5.5 \mathrm{mmol}$. liter $^{-1}$ ) in a dose-dependent manner. We have also shown a suppression of insulin release by leptin in perifused rat islets. To confirm whether these effects are via a direct action on the $\beta$ cell, we treated clonal insulinoma cells with leptin, and a dose-dependent inhibitory effect of the adipocyte-derived hormone in three different cell lines was observed. This is supported by the observation that OB-Rb mRNA was present in the islets and cell lines as recently reported by RNase protection assay (13). The batch of leptin used in these studies was estimated to be $>90 \%$ pure by SDS-PAGE. The remaining material was composed of three main elements, leptin dimer, leptin with one to three amino acids lost from the $\mathrm{NH}_{2}$ terminus (all these leptins are equally active as a full-length monomer), and a small amount of unidentified material, assumed to be bacterial protein. The leptin was entirely without activity in leptin receptor-defective $d b / d b$ mouse and did not alter insulin secretion stimulated by arginine or tolbutamide in the $\beta$ TC6 cells, suggesting that it is unlikely that there is any nonspecific effects of the small quantity of unknown material. Pilot studies carried out in our laboratory have shown that addition of BSA

Table I. Effect of Leptin on Tolbutamide- and Arginine-stimulated Insulin Secretion in $\beta$ TC6 Cells

\begin{tabular}{|c|c|c|c|c|c|c|}
\hline & Control & $\begin{array}{c}\text { Tolbutamide } \\
\left(100 \mu \mathrm{mol} \cdot \text { liter }^{-1}\right)\end{array}$ & $\begin{array}{c}\text { Tolbutamide }\left(100 \mu \mathrm{mol} \cdot \mathrm{l}^{-1}+\right. \\
\text { leptin }\left(1 \mathrm{nmol} \cdot \text { liter }^{-1}\right)\end{array}$ & Control & $\begin{array}{c}\text { Arginine } \\
\left(10 \mathrm{mmol}^{\prime} \text { liter }^{-1}\right)\end{array}$ & $\begin{array}{l}\text { Arginine }\left(10 \mathrm{mmol} \cdot \text { liter }^{-1}\right)+ \\
\text { leptin }\left(1 \mathrm{nmol} \cdot \text { liter }^{-1}\right)\end{array}$ \\
\hline \multicolumn{7}{|l|}{ Insulin secretion } \\
\hline$\left(\mathrm{pmol} / 10^{6}\right.$ cells $\left.\cdot \mathrm{h}^{-1}\right)$ & $18.5 \pm 1.4$ & $31.5 \pm 1.6 *$ & $30.0 \pm 2.2 *$ & $18.5 \pm 1.2$ & $33.2 \pm 3.2 *$ & $34.6 \pm 2.8 *$ \\
\hline
\end{tabular}

Cells were incubated in glucose-free, serum-free medium for $2 \mathrm{~h}$ with $100 \mu \mathrm{mol} \cdot$ liter $^{-1}$ tolbutamide or $10 \mathrm{mmol} \cdot$ liter ${ }^{-1}$ arginine with or without addition of leptin $\left(1 \mathrm{nmol} \cdot\right.$ liter $\left.^{-1}\right)$ and insulin release measured by RIA of the media. Data are mean values \pm SE. The comparisons between groups were made using ANOVA with post-hoc Tukey test. $* P<0.05$ vs. control, $n=6$ each. 
a

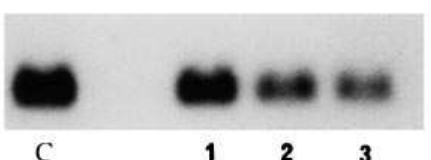

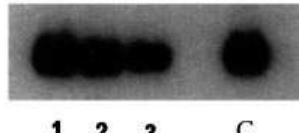

123

C

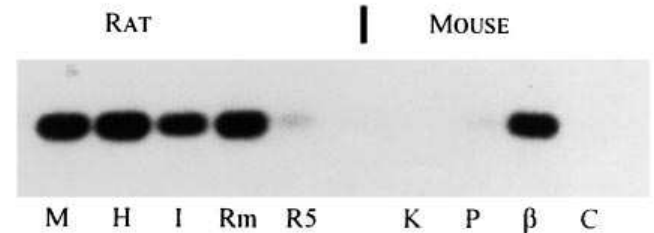

Figure 3. (a) Representative Northern blots of insulin mRNA in rat islets (left) and $\beta$ TC6 cells (right) $(n=4)$. $C$, Control; $1,0.1 ; 2,1 ; 3,10$ $\mathrm{nmol} \cdot$ liter $^{-1}$ leptin. (b) Southern blot analysis of the RT-PCR products showing leptin receptor mRNA in rat tissues ( $M$, skeletal muscle; $H$, hypothalamus; $I$, islets), rat insulinoma cell lines ( $R m$, RIN m5F; $R 5$, RIN 5AH), mouse tissues ( $K$, kidney; $P$, pancreas; $C$, colon), and a mouse insulinoma cell line ( $\beta, \beta$ TC6 $), n=3$.

$(0.4 \%)$ inhibits insulin release in $\beta$ TC6 cells by $>\sim 40 \%$. The mechanism of inhibition of insulin secretion by albumin is unclear. However, in these conditions, addition of leptin up to $1 \mathrm{nmol} \cdot$ liter $^{-1}$ produced no greater inhibition in these cells

Table II. Effect of Leptin on $\left[\mathrm{Ca}^{2+}\right]_{I}\left(\right.$ nmol $\cdot$ liter $\left.{ }^{-1}\right)$ Levels in $\beta$ TC6 Cells

\begin{tabular}{cccc}
\hline & Control + & Tolbutamide & Tolbutamide $(100$ \\
& leptin $(1 \mathrm{nmol} \cdot 100 \mu \mathrm{mol} \cdot$ & $\left.\mu \mathrm{mol} \cdot \operatorname{liter}^{-1}\right)+$ leptin \\
Control & $\left.\operatorname{liter}^{-1}\right)$ & liter $\left.^{-1}\right)$ & $\left(1 \mathrm{nmol} \cdot\right.$ liter $\left.^{-1}\right)$
\end{tabular}

$\left[\mathrm{Ca}^{2+}\right]_{\mathrm{I}}$

(nmol/liter) $251 \pm 42 \quad 202 \pm 51 \quad 766 \pm 108 * \quad 815 \pm 97 *$

Intracellular calcium was measured by analysis of Fura-2 fluorescence in cell suspensions as described in Methods. Data are mean values \pm SE. The comparisons between groups were made using ANOVA with posthoc Tukey test. $* P<0.05$ vs. control, $n=5$ each.

(our unpublished observations). Further, leptin is thought to be present in FCS (34) and a large proportion of plasma leptin (up to $98 \%$ in lean humans) has been reported to be bound to serum proteins (35). These observations indicate that the effects of exogenous leptin may be diminished or obliterated in the presence of BSA or FCS. Therefore, we carried out all experiments on these cells in buffer devoid of BSA. The effect of leptin was powerful, with inhibition evident at concentrations in the range $1-1,000 \mathrm{pmol} \cdot$ liter $^{-1}$. Leptin, at a similar concen-

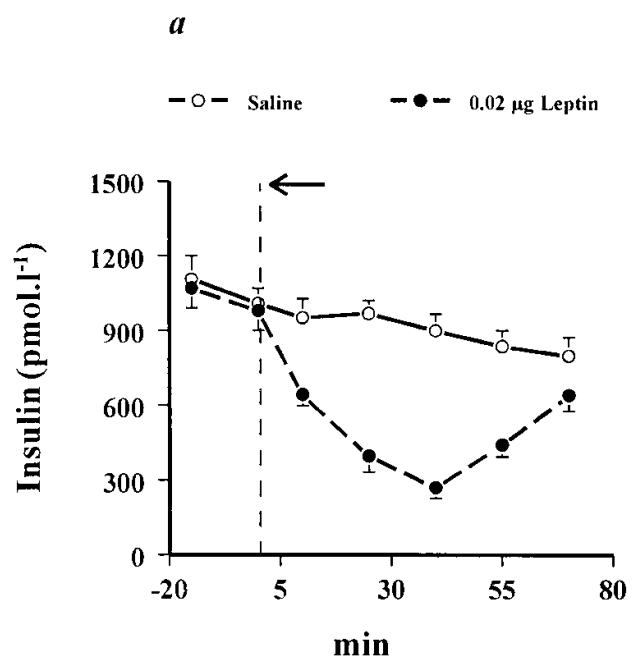

$c$

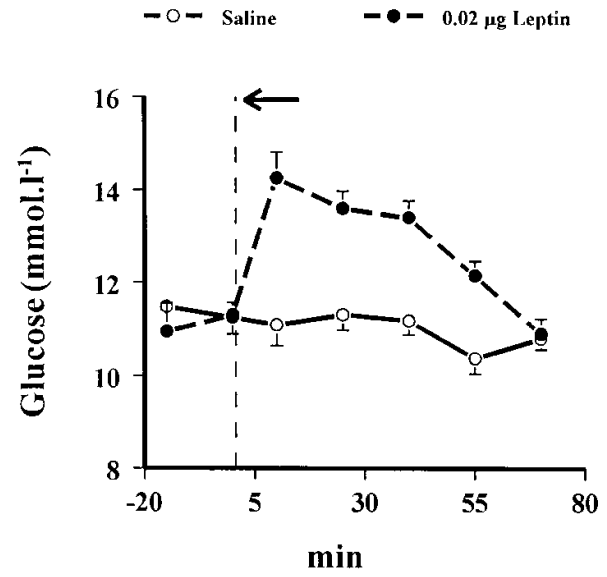

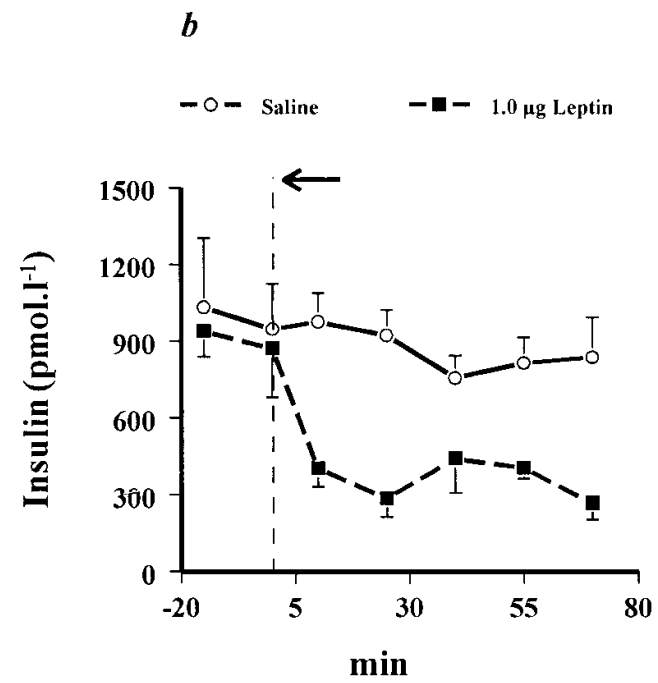

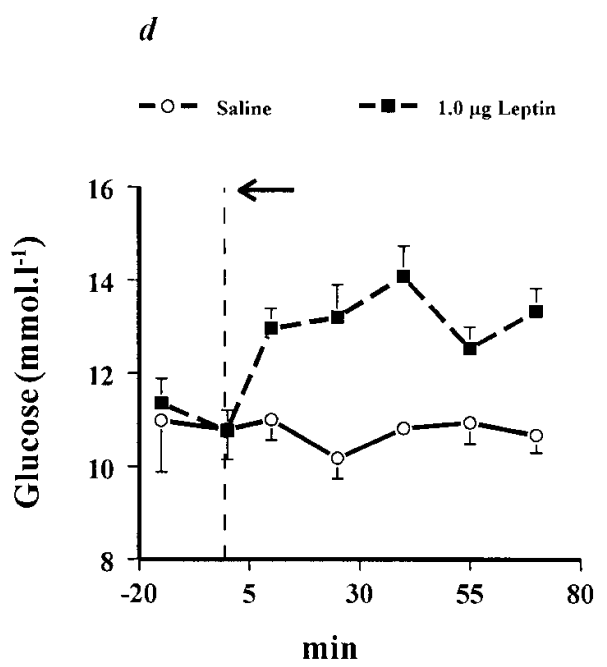

Figure 4. Effect of leptin on plasma insulin and glucose levels in fed normal mice injected $(\leftarrow)$ with saline or leptin. AUC between 0 and $70 \mathrm{~min}$ (AUC 0-70) expressed as mean \pm SE: Insulin nmol $\operatorname{liter}^{-1} \cdot \min (a$ and $b)$, Control $-2 \pm 7$ (open circles) vs. $0.02 \mu \mathrm{g} \cdot \mathrm{g}^{-1}$ body wt leptin $-25 \pm 8$ (filled circles), $P<0.05$; Control $4 \pm 9$ (open circles) vs. 1.0 $\mu \mathrm{g} \cdot \mathrm{g}^{-1}$ body wt leptin $-33 \pm 7$ (filled boxes), $P<$ 0.01 . Glucose, mmol · liter $^{-1} \cdot \min (c$ and $d)$, Control $-3.6 \pm 28$ (open circles) vs. $0.02 \mu \mathrm{g} \cdot \mathrm{g}^{-1}$ body wt leptin $151 \pm 34$ (filled circles), $P<0.05$ Control $-10 \pm 58$ (open circles) vs. $1.0 \mu \mathrm{g} \cdot \mathrm{g}^{-1}$ body wt leptin $123 \pm 32$ (filled boxes), $P<0.01$. $n=5-10$ mice per time point per group. Data are mean values \pm SE. The comparisons between groups were made using ANOVA with post-hoc Tukey test. 
Table III. Plasma Glucose and Insulin Concentrations 25 min after Intraperitoneal Injection of Saline (Control) or Leptin in Normal (Fed and Overnight Fasted), ob/ob, and db/db Mice

\begin{tabular}{|c|c|c|c|c|c|c|}
\hline \multirow[b]{2}{*}{ Mice } & \multirow[b]{2}{*}{ Condition } & \multirow{2}{*}{$\begin{array}{c}\text { Leptin dose } \\
\left(\mu \mathrm{g} \cdot \mathrm{g}^{-1} \text { body wt }\right)\end{array}$} & \multicolumn{2}{|c|}{ Glucose $\left(\mathrm{mmol} \cdot\right.$ liter $\left.^{-1}\right)$} & \multicolumn{2}{|c|}{ Insulin $\left(\mathrm{pmol} \cdot \operatorname{liter}^{-1}\right)$} \\
\hline & & & Saline & Leptin & Saline & Leptin \\
\hline Normal & Fast & 1.0 & $6.5 \pm 0.4$ & $7.1 \pm 0.4$ & $140 \pm 11$ & $145 \pm 15$ \\
\hline Normal & Fed & 0.02 & $11.3 \pm 0.3$ & $13.6 \pm 0.4 *$ & $969 \pm 52$ & $396 \pm 64^{\ddagger}$ \\
\hline Normal & Fed & 1.0 & $10.2 \pm 0.5$ & $13.2 \pm 0.7^{\S}$ & $924 \pm 98$ & $288 \pm 73^{\ddagger}$ \\
\hline$o b / o b$ & Fed & 0.02 & $12.5 \pm 0.5$ & $26.0 \pm 4.1 *$ & $5565 \pm 1248$ & $1340 \pm 247^{\S}$ \\
\hline$d b / d b$ & Fed & 0.2 & $27.4 \pm 1.7$ & $27.6 \pm 2.4$ & $3587 \pm 389$ & $3833 \pm 464$ \\
\hline$d b / d b$ & Fed & 0.02 & $25.8 \pm 3.2$ & $26.8 \pm 2.1$ & $3392 \pm 419$ & $3268 \pm 349$ \\
\hline$d b /+$ and $+/+$ & Fed & 0.2 & $9.7 \pm 0.4$ & $12.2 \pm 0.4^{\S}$ & $959 \pm 148$ & $254 \pm 48^{\ddagger}$ \\
\hline
\end{tabular}

Plasma insulin was measured by RIA and glucose by the glucose oxidase method. Data are mean values \pm SE. The comparisons between groups were made using ANOVA with post-hoc Tukey test. ${ }^{*} P<0.05,{ }^{\S} P<0.01,{ }^{\ddagger} P<0.001$ vs. saline, $n=5-10$ per group.

tration of $1 \mathrm{pmol} \cdot$ liter $^{-1}$, has also been shown to increase luteinizing hormone-releasing hormone in median eminencearcuate nuclear explants (36).

To study if the inhibitory effects of leptin were evident in the presence of stimulatory agents other than glucose, $\beta$ TC6 cells were treated with $100 \mu \mathrm{mol} \cdot$ liter $^{-1}$ tolbutamide and 10 $\mathrm{mmol} \cdot$ liter $^{-1}$ arginine in the presence and absence of $1 \mathrm{nmol}$. liter $^{-1}$ leptin. A nearly twofold stimulation of insulin release was observed after the addition of tolbutamide and arginine. Leptin at the tested concentration of $1 \mathrm{nmol} \cdot \operatorname{liter}^{-1}$ did not inhibit insulin release induced by these agents. It is possible that higher concentrations of leptin may be needed to inhibit insulin release in the presence of these stimulatory agents. In the clonal $\beta$ TC6 cells, the inhibitory effect of leptin was associated with an $\sim 20 \%$ decrease in $\left[\mathrm{Ca}^{2+}\right]_{\mathrm{I}}$. Although the observed decrease in these tumor cells was not significantly different from control values, Kieffer et al. (37) have reported recently a decrease in $\left[\mathrm{Ca}^{2+}\right]_{\mathrm{I}}$ after an action on the adenosine triphosphate potassium $\left(\mathrm{K}_{\mathrm{ATP}}\right)$ channel in $\beta$ cells isolated from $o b / o b$ mice. Thus, while it is likely that leptin may suppress insulin secretion by acting on the $\mathrm{K}_{\mathrm{ATP}}$ channel, other mechanisms such as intracellular lipolysis and increased fatty acid oxidation may also play a role (38). Further detailed studies are required to explore the mechanism of action of leptin in native $\beta$ cells isolated from normal mice.

To investigate the physiological significance of these findings in vivo, we injected leptin into normal fed mice at two doses. The decrease in insulin release in response to both doses along with a corresponding increase in glucose levels suggests that leptin is able to acutely suppress insulin secretion in normal animals. Reported circulating concentrations of leptin are $3.9 \pm 0.4$ in fed lean mice and $4.0 \pm 0.5 \mathrm{ng} \cdot \mathrm{ml}^{-1}$ in rats $(31,33)$. Leptin levels are reported to be 5 -fold higher in mice fed a high-fat diet (39), 10- and 5-fold higher in $\mathrm{db} / \mathrm{db}$ and fat/ fat mice relative to littermate controls, respectively (40), and are elevated by as much as 50 -fold in fatty $(f a / f a)$ rats $(40,41)$. In humans, the levels vary from $12 \pm 4 \mathrm{ng} \cdot \mathrm{ml}^{-1}$ (lean) to $42 \pm 9$ $\mathrm{ng} \cdot \mathrm{ml}^{-1}$ (obese) (42). Therefore, the insulin suppressive effect observed in normal fed mice is evident at plasma concentrations $\left(11 \pm 4 \mathrm{ng} \cdot \mathrm{ml}^{-1}\right)$ similar to those in mice fed a high-fat diet, and in humans, suggesting a hormonal role for leptin in the modulation of postprandial insulin secretion. Interestingly, in fasted animals no effect of leptin on plasma insulin and glucose concentrations was observed. No obvious explanation for this differential effect is apparent but it suggests that leptin either acts to inhibit a postprandial stimulator of insulin release or in the fasting state a similar inhibitor already acts which is absent after food intake. In $d b / d b$ mice, used as negative controls, injection of leptin failed to alter insulin or glucose levels, supporting the study carried out on the perfused pancreas of Zucker fa/fa rats (13). Both of these rodent models have a mutant leptin receptor and show reduced sensitivity or no response to leptin $(4,6,38,43-46)$.

These results demonstrate leptin inhibition of insulin secretion in the whole animal and a direct effect on the rodent and human islet. Leptin also inhibits insulin mRNA expression in both $\beta$ TC6 cells and rat islets. Insulin is known to enhance leptin synthesis and release in rodents and humans, although the time course of these effects is different $(9,10)$. Inhibition of insulin secretion by leptin thus appears to form a feedback loop. Insulin also stimulates lipogenesis (47), contributes to the regulation of fat mass, and thus to plasma leptin concentrations, apparently forming a second, longer term feedback.

Administration of leptin to $o b / o b$ mice resulted within minutes in a suppression of insulin secretion and gross exacerbation of the hyperglycemia. Repeated administration of leptin to the $o b / o b$ mouse decreases food intake over the subsequent days, with an associated weight loss and marked decrease in peripheral insulin resistance $(4,5)$. This latter effect appears dominant over any direct suppression of insulin secretion by leptin, since plasma glucose concentration falls. The results shown in our study relate to acute changes in insulin levels observed within minutes of leptin injection and are not inconsistent with earlier reports $(4,5,30,46)$. In these reports, alterations in plasma glucose and insulin concentrations are observed several hours or days after leptin injection and are likely to involve a complex set of changes in other regulatory factors, for example in plasma cortisol levels $(30,31)$, hypothalamic neuropeptide Y $(45,46)$ or norepinephrine $(48)$, or in brown fat activation (49).

In obese humans, behavioral override may prevent the effect of leptin on food intake but may leave intact the inhibition of insulin release. Leptin acts indirectly on the hypothalamus, being dependent on rate-limiting transport into the central 
nervous system. Reduced central nervous system access has been reported at higher plasma leptin concentrations (2). The pancreatic $\beta$ cell is in direct plasma contact and thus not affected by rate-limiting transport. In severe human obesity, leptin may act to worsen carbohydrate intolerance and form one mechanism by which increased body fat is associated with diabetes mellitus. We conclude that the effects of circulating leptin on insulin secretion, at least in obese mice, are likely to be physiologically important since glucose tolerance is acutely impaired at apparent physiological leptin concentrations.

\section{Acknowledgments}

Dr. M. Chiesi and Dr. N. Levens from Ciba-Geigy Ltd. are thanked for providing the recombinant mouse leptin. We thank Dr. N.J. London and Dr. R.F.L. James (Leicester Royal Infirmary) for providing the human islets.

This study was supported by the Medical Research Council, UK, The British Diabetic Association, and The Special Trustees of Hammersmith Hospital, UK. Rohit N. Kulkarni is the recipient of the Overseas Research Students Award and the Weston Scholarship.

\section{References}

1. Zhang, Y., R. Proenca, M. Maffei, M. Barone, L. Leopold, and J.M. Friedman. 1994. Positional cloning of the mouse obese gene and its human homologue [published erratum appears in Nature. 1995. 374:479]. Nature. 372:425432.

2. Schwartz, M.W., E. Peskind, M. Raskind, E.J. Boyko, and D. Porte, Jr. 1996. Cerebrospinal fluid leptin levels: relationship to plasma levels and to adiposity in humans. Nat. Med. 2:589-593.

3. Considine, R.V., M.K. Sinha, M.L. Heiman, A. Kriauciunas, T.W. Stephens, M.R. Nyce, J.P. Ohannesian, C.C. Marco, L.J. McKee, T.L. Bauer, and J.F. Caro. 1996. Serum immunoreactive-leptin concentrations in normalweight and obese humans. N. Engl. J. Med. 334:292-295.

4. Halaas, J.L., K.S. Gajiwala, M. Maffei, S.L. Cohen, B.T. Chait, D. Rabinowitz, R.L. Lallone, S.K. Burley, and J.M. Friedman. 1995. Weightreducing effects of the plasma protein encoded by the obese gene. Science. 269: 543-546.

5. Pelleymounter, M.A., M.J. Cullen, M.B. Baker, R. Hecht, D. Winters, T. Boone, and F. Collins. 1995. Effects of the obese gene product on body weight regulation in ob/ob mice. Science. 269:540-543.

6. Campfield, L.A., F.J. Smith, Y. Guisez, R. Devos, and P. Burn. 1995. Recombinant mouse OB protein: evidence for a peripheral signal linking adiposity and central neural networks. Science. 269:546-549.

7. Gainsford, T., T.A. Willson, D. Metcalf, E. Handman, C. McFarlane, A. $\mathrm{Ng}$, N.A. Nicola, W.S. Alexander, and D.J. Hilton. 1996. Leptin can induce proliferation, differentiation, and functional activation of hemopoietic cells. Proc. Natl. Acad. Sci. USA. 93:14564-14568.

8. Cohen, B., D. Novick, and M. Rubinstein. 1996. Modulation of insulin activities by leptin. Science. 274:1185-1188.

9. Saladin, R., P. De Vos, M. Guerre Millo, A. Leturque, J. Girard, B. Staels, and J. Auwerx. 1995. Transient increase in obese gene expression after food intake or insulin administration. Nature. 377:527-529.

10. Malmstrom, R., M.R. Taskinen, S.L. Karonen, and H. Yki Jarvinen. 1996. Insulin increases plasma leptin concentrations in normal subjects and patients with NIDDM. Diabetologia. 39:993-996.

11. Segal, K.R., M. Landt, and S. Klein. 1996. Relationship between insulin sensitivity and plasma leptin concentration in lean and obese men. Diabetes. 45 : 988-991.

12. Kieffer, T.J., R.S. Heller, and J.F. Habener. 1996. Leptin receptors expressed on pancreatic beta-cells. Biochem. Biophys. Res. Commun. 224:522527

13. Emilsson, V., Y.L. Liu, M.A. Cawthorne, N.M. Morton, and M. Davenport. 1997. Expression of the functional leptin receptor mRNA in pancreatic islets and direct inhibitory action of leptin on insulin secretion. Diabetes. 46:313316.

14. Leclercq Meyer, V., R.V. Considine, A. Sener, and W.J. Malaisse. 1996. Do leptin receptors play a functional role in the endocrine pancreas? Biochem. Biophys. Res. Commun. 229:794-798.

15. Rentsch, J., N. Levens, and M. Chiesi. 1995. Recombinant ob-gene product reduces food intake in fasted mice. Biochem. Biophys. Res. Commun. 214:131-136.

16. Wang, Z.L., W.M. Bennet, M.A. Ghatei, P.G. Byfield, D.M. Smith, and
S.R. Bloom. 1993. Influence of islet amyloid polypeptide and the 837 fragment of islet amyloid polypeptide on insulin release from perifused rat islets. Diabetes. 42:330-335.

17. Lacy, P.E., and M. Kostianovsky. 1967. Method for the isolation of intact islets of Langerhans from the rat pancreas. Diabetes. 16:35-39.

18. Bennet, W.M., Z.L. Wang, P.M. Jones, R.M. Wang, R.F. James, N.J London, M.A. Ghatei, and S.R. Bloom. 1996. Presence of neuropeptide Y and its messenger ribonucleic acid in human islets: evidence for a possible paracrine role. J. Clin. Endocrinol. Metab. 81:2117-2120.

19. Albano, J.D., R.P. Ekins, G. Maritz, and R.C. Turner. 1972. A sensitive precise radioimmunoassay of serum insulin relying on charcoal separation of bound and free hormone moieties. Acta Endocrinol. Copenh. 70:487-509.

20. Knaack, D., D.M. Fiore, M. Surana, M. Leiser, M. Laurance, D. Fusco DeMane, O.D. Hegre, N. Fleischer, and S. Efrat. 1994. Clonal insulinoma cell line that stably maintains correct glucose responsiveness. Diabetes. 43:14131417

21. Kulkarni, R.N., Z.L. Wang, K.O. Akinsanya, W.M. Bennet, R.M. Wang, D.M. Smith, M.A. Ghatei, P.G. Byfield, and S.R. Bloom. 1995. Pyroglutamylphenylalanyl-proline amide attenuates thyrotropin-releasing hormone-stimulated insulin secretion in perifused rat islets and insulin-secreting clonal betacell lines. Endocrinology. 136:5155-5164.

22. Chomczynski, P., and N. Sacchi. 1987. Single-step method of RNA isolation by acid guanidinium thiocyanate-phenol-chloroform extraction. Anal. Biochem. 162:156-159.

23. Ferrier, G.J., A.M. Pierson, P.M. Jones, S.R. Bloom, S.I. Girgis, and S Legon. 1989. Expression of the rat amylin (IAPP/DAP) gene. J. Mol. Endocrinol. 3:R14.

24. Smith, D.M., S.R. Bloom, M.C. Sugden, and M.J. Holness. 1992. Glucose transporter expression and glucose utilization in skeletal muscle and brown adipose tissue during starvation and refeeding. Biochem. J. 282:231-235.

25. Tartaglia, L.A., M. Dembski, X. Weng, N. Deng, J. Culpepper, R. Devos, G.J. Richards, L.A. Campfield, F.T. Clark, J. Deeds, et al. 1995. Identification and expression cloning of a leptin receptor, OBR. Cell. 83:1263-1271.

26. Beak, S.A., C.J. Small, I. Ilovaiskaia, J.D. Hurley, M.A. Ghatei, S.R. Bloom, and D.M. Smith. 1996. Glucagon-like peptide-1 (GLP-1) releases thyrotropin (TSH): characterization of binding sites for GLP-1 on alpha-TSH cells Endocrinology. 137:4130-4138.

27. Tsien, R.Y., T. Pozzan, and T.J. Rink. 1982. T-cell mitogens cause early changes in cytoplasmic free $\mathrm{Ca}^{2+}$ and membrane potential in lymphocytes. $\mathrm{Na}$ ture. 295:68-71.

28. Nanberg, E., and E. Rozengurt. 1988. Temporal relationship between inositol polyphosphate formation and increases in cytosolic $\mathrm{Ca}^{2+}$ in quiescent 3T3 cells stimulated by platelet-derived growth factor, bombesin and vasopressin. EMBO (Eur. Mol. Biol. Organ.) J. 7:2741-2747.

29. Wang, Z., R.M. Wang, A.A. Owji, D.M. Smith, M.A. Ghatei, and S.R. Bloom. 1995. Glucagon-like peptide-1 is a physiological incretin in rat. J. Clin. Invest. 95:417-421.

30. Ghilardi, N., S. Ziegler, A. Wiestner, R. Stoffel, M.H. Heim, and R.C. Skoda. 1996. Defective STAT signaling by the leptin receptor in diabetic mice. Proc. Natl. Acad. Sci. USA. 93:6231-6235.

31. Ahima, R.S., D. Prabakaran, C. Mantzoros, D. Qu, B. Lowell, E. Maratos Flier, and J.S. Flier. 1996. Role of leptin in the neuroendocrine response to fasting. Nature. 382:250-252.

32. Coleman, D.L. 1978. Obese and diabetes: two mutant genes causing diabetes-obesity syndromes in mice. Diabetologia. 14:141-148.

33. Hardie, L.J., D.V. Rayner, S. Holmes, and P. Trayhurn. 1996. Circulating leptin levels are modulated by fasting, cold exposure and insulin administration in lean but not Zucker (fa/fa) rats as measured by ELISA. Biochem. Biophys. Res. Commun. 223:660-665.

34. Bennett, B.D., G.P. Solar, J.Q. Yuan, J. Mathias, G.R. Thomas, and W. Matthews. 1996. A role for leptin and its cognate receptor in hematopoiesis. Curr. Biol. 6:1170-1180.

35. Sinha, M.K., I. Opentanova, J.P. Ohannesian, J.W. Kolaczynski, M.L. Heiman, J. Hale, G.W. Becker, R.R. Bowsher, T.W. Stephens, and J.F. Caro. 1996. Evidence of free and bound leptin in human circulation. Studies in lean and obese subjects and during short-term fasting. J. Clin. Invest. 98:1277-1282.

36. Yu, W.H., M. Kimura, A. Walczewska, S. Karanth, and S.M. McCann. 1997. Role of leptin in hypothalamic-pituitary function. Proc. Natl. Acad. Sci. USA. 94:1023-1028.

37. Kieffer, T.J., R.S. Heller, C.A. Leech, G.G. Holz, and J.F. Habener. 1997. Leptin suppression of insulin secretion by the activation of ATP-sensitive $\mathrm{K}+$ channels in pancreatic $\beta$ cells. Diabetes. 46:1087-1093.

38. Shimabukuro, M., K. Koyama, G. Chen, M.-Y. Wang, F. Trieu, Y. Lee C.B. Newgard, and R.H. Unger. 1997. Direct antidiabetic effect of leptin through triglyceride depletion of tissues. Proc. Natl. Acad. Sci. USA. 94:46374641 .

39. Frederich, R.C., A. Hamann, S. Anderson, B. Lollmann, B.B. Lowell, and J.S. Flier. 1995. Leptin levels reflect body lipid content in mice: evidence for diet-induced resistance to leptin action. Nat. Med. 1:1311-1314.

40. Maffei, M., J. Halaas, E. Ravussin, R.E. Pratley, G.H. Lee, Y. Zhang, H. Fei, S. Kim, R. Lallone, S. Ranganathan, et al. 1995. Leptin levels in human and rodent: measurement of plasma leptin and ob RNA in obese and weight-reduced 
subjects. Nat. Med. 1:1155-1161.

41. Truett, G.E., N. Bahary, J.M. Friedman, and R.L. Leibel. 1991. Rat obesity gene fatty (fa) maps to chromosome 5: evidence for homology with the mouse gene diabetes (db). Proc. Natl. Acad. Sci. USA. 88:7806-7809.

42. Sinha, M.K., J.P. Ohannesian, M.L. Heiman, A. Kriauciunas, T.W. Stephens, S. Magosin, C. Marco, and J.F. Caro. 1996. Nocturnal rise of leptin in lean, obese, and non-insulin-dependent diabetes mellitus subjects. J. Clin. Invest. 97:1344-1347.

43. Levin, N., C. Nelson, A. Gurney, R. Vandlen, and F. de Sauvage. 1996. Decreased food intake does not completely account for adiposity reduction after ob protein infusion. Proc. Natl. Acad. Sci. USA. 93:1726-1730.

44. Iida, M., T. Murakami, K. Ishida, A. Mizuno, M. Kuwajima, and K. Shima. 1996. Phenotype-linked amino acid alteration in leptin receptor cDNA from Zucker fatty (fa/fa) rat. Biochem. Biophys. Res. Commun. 222:19-26.

45. Stephens, T.W., M. Basinski, P.K. Bristow, J.M. Bue Valleskey, S.G. Burgett, L. Craft, J. Hale, J. Hoffmann, H.M. Hsiung, A. Kriauciunas, et al. 1995. The role of neuropeptide $\mathrm{Y}$ in the antiobesity action of the obese gene product. Nature. 377:530-532.

46. Schwartz, M.W., D.G. Baskin, T.R. Bukowski, J.L. Kuijper, D. Foster, G. Lasser, D.E. Prunkard, D. Porte, Jr., S.C. Woods, R.J. Seeley, and D.S. Weigle. 1996. Specificity of leptin action on elevated blood glucose levels and hypothalamic neuropeptide Y gene expression in ob/ob mice. Diabetes. 45:531-535.

47. Steinberg, D. 1992. The endocrine pancreas. In The Physiological Basis of Medical Practice. J.B. West, editor. Williams and Wilkins, Baltimore. 760763.

48. Shi, C.L., J. Sehlin, I.B. Taljedal, N.G. Morgan, and W. Montague. 1985. Effects of UK-14,304, noradrenaline, and propranolol on insulin release from transplanted mouse islets. Studies on the mechanism of inhibition of glucosestimulated insulin secretion by noradrenaline in rat islets of Langerhans. Eur. J. Endocrinol. 226:571-576.

49. Cooney, G.J., M.A. Vanner, J.L. Nicks, P.F. Williams, and I.D. Caterson. 1989. Changes in the lipogenic response to feeding of liver, white adipose tissue and brown adipose tissue during the development of obesity in the goldthioglucose-injected mouse. Biochem. J. 259:651-657. 